\title{
Trust, Accountability and Capacity in Education System Reform
}

Global Perspectives in Comparative Education

Edited by

Melanie Ehren and Jacqueline Baxter

First published in 2021

ISBN 978-0-367-36247-8 (hbk)

ISBN 978-0-367-36249-2 (pbk)

ISBN 978-0-429-34485-5 (ebk)

\section{Chapter 11}

Contrasting approaches, comparable efficacy?: How macro-level trust influences teacher accountability in Finland and Singapore

Yue-Yi Hwa

CC-BY 


\section{1}

\section{CONTRASTING APPROACHES, COMPARABLE EFFICACY?}

\section{How macro-level trust influences teacher accountability in Finland and Singapore}

\section{Yue-Yi Hwa}

\section{Introduction}

On today's educational stage, Finland and Singapore cast outsized shadows. Since gaining the spotlight with standout performances in PISA and TIMSS, these relatively small countries - each weighing in at roughly 5.5 million people (United Nations, 2017) - have featured in policy discussions and media reports worldwide. It has become commonplace to see headlines such as 'Scotland eyes Singapore in "radical” overhaul of teaching career paths' (Hepburn, 2017) or 'Highly trained, respected and free: why Finland's teachers are different' (Crouch, 2015).

Yet, as these headlines suggest, Finland's and Singapore's respective teaching professions are lauded for different traits. While international commentary often highlights Singapore's teaching career progression that creates incentives for teachers to incrementally develop their practice (e.g. Nelson, 2016), discussions about Finland frequently focus on the professional autonomy that its teachers enjoy (e.g. Crouch, 2015). These differences derive from disparate approaches to teacher accountability. Singapore has an extensive teacher performance management system incorporating detailed performance standards, regular formal appraisals, a career ladder and competition-based salary bonuses (Kan, 2014; Sclafani and Lim, 2008). In contrast, the teaching profession in Finland has minimal rewards and penalties, with neither formal evaluation nor promotion (Finnish National Board of Education, 2013; Sahlberg, 2015).

Strikingly, these disparate approaches to teacher accountability both appear to be effective. Notwithstanding Singapore's recent dominance of TIMSS and PISA league tables and Finland's recent declines in the same (Martin et al., 2016a,b; OECD, 2016), both the education systems continue to receive international adulation, and justifiably so. What accounts for these different pathways to comparable educational success? 
I propose that the answer lies in how teacher accountability instruments affect teacher motivation, and how this accountability-motivation link is shaped by sociocultural patterns in the macrosystem. To preview the argument, one crucial macrosystemic pattern is that both the countries enjoy high public trust in the education system - but this trust is distributed differently across the two systems. In Finland, public trust permeates every level of the education system. Accordingly, at the classroom level, teachers are trusted to work autonomously, with little formal monitoring. However, in Singapore, public trust is focused upon the Ministry of Education and its capacity to deliver good learning outcomes system-wide - hence the extensive, centrally steered system for managing the teachers' performance. Despite these differences, both the systems experience a similar feedback loop between trust, accountability and teacher motivation: the distribution of trust legitimates the choice of teacher accountability instruments,

\section{BOX 1: INTERVIEW METHODS}

In this chapter, I draw on interviews with 12 teachers from 11 different secondary schools in Singapore (for pupils from ages 13 to 16/17), and 12 teachers from 10 lower secondary schools in Finland (for ages 13-15). The interviews were conducted during July 2018 and September 2018, respectively. These interviews are part of a larger mixed-methods research project on teacher accountability policy and sociocultural context across countries, which also include statistical analysis of sociocultural surveys and international largescale assessments. Accordingly, I interviewed teachers in the level of schooling that corresponded with PISA and TIMSS (Grade 8) participation.

The sample of participants was not chosen systematically, since I relied on personal and professional networks for participant recruitment. However, I ensured that participants varied in the subjects they taught, their teaching experience, administrative roles and school types, and also in personal characteristics such as gender, ethnolinguistic background and whether they grew up in the country or abroad. Each teacher participated in one individual interview, which was audio recorded and subsequently transcribed. I then coded the transcripts using a coding scheme that was based on the theoretical framework and research questions, with revisions and additions to accommodate themes arising in the corpus. Portions of the coded data were summarised into matrices, to give a visual overview of the corpus without the misleading appearance of precision that would accompany percentages or other numerical summaries. Finally, I reread each transcript in full to ensure that the matrices and illustrative quotes accurately represented each interview. Participants are identified by pseudonyms, and interview quotes have been edited for readability. For further details about interview methods, see Hwa (2019). 
which means that teachers respond to the instruments positively, which, in turn, contributes to desirable student outcomes that reinforce the distribution of trust.

\section{Teacher accountability in Finland and Singapore}

If we think of teacher accountability instruments as structures or practices that (1) set standards, (2) convey information and (3) allocate rewards and penalties for teacher practice, ${ }^{1}$ Finland and Singapore differ in all the three categories. In Singapore, all teachers are subject to the education ministry's Enhanced Performance Management System (EPMS), which codifies extensive standards for teacher practice, collects detailed information on teachers' work and administers a complicated system of rewards and penalties for teacher performance. In the words of Mark, an interview participant from Singapore:

I really do think that the EPMS works well for the identification of teachers who are in need of support, and the identification of teachers who are in need of greater opportunity in order to stretch them for greater impact. I also think that, on a simple day-to-day level, [...] it helps to guide the work of every general education officer and senior education officer in the system. [...] Now, from an incentives perspective, it certainly incentivises hard work, if it's done fairly.

In contrast, Finland sets high standards at the point of entry into the teaching profession, through highly selective admissions to teacher training and extensive socialisation during this training. But once teachers are in classrooms, their school leaders, municipal officials and central government authorities generally assume that they are doing their jobs well, unless complaints from students or parents indicate otherwise. According to Finnish interview participant Helena,

You don't need as many control tools when the assumption is that we teachers are professionals who know their job and have the skills, and that we are all interested in the same goals and in delivering the curriculum.

In the rest of this section, I explore these contrasts between Finland's and Singapore's teacher accountability approaches in more detail.

\section{Setting standards for teacher practice}

Finland's teacher accountability system operates primarily by setting high standards for teacher practice. Almost every interview participant named the national curriculum as an accountability instrument. Even if some teachers may not always comply with curricular minutiae, they still value its standard-setting role. For example, while calling the current curriculum 'very complicated to understand' 
and 'sometimes unclear', and saying that there were probably some curricular expectations that she was not fulfilling, Finnish participant Liisa also said:

Well, we need to have a national curriculum. It's definitely a 'must'. If we didn't have it, then we would not have a common ground for the students to continue on to upper secondary school.

In addition to agreeing that the curriculum was important, participants also agreed that it left them substantial freedom in their practice. In Anneli's words, 'The national curriculum gives us guidelines, but I can still do my work the way that I feel is the best way for me, and for my students.'

However, a strong national curriculum is hardly a unique feature among education systems worldwide. Arguably more important than the curriculum are the standards set by Finland's famously stringent admissions processes for teacher training (Malinen et al., 2012; Muhonen, 2017), as well as its rigorous, master's-level teacher training programmes (Sahlberg, 2015; Tirri, 2014). Admissions standards and pre-service training may not fit some conceptions of teacher accountability instruments, but they undoubtedly play a role in Finnish teacher accountability. Admissions standards ensure that those who are chosen to enter the profession are highly motivated to teach well, while pre-service training ingrains the expertise that orients their motivation towards effective practices. Although a few interview participants mentioned neither the admissions criteria nor the pre-service training, this is probably because such point-of-entry instruments may be taken for granted in teachers' day-to-day work. ${ }^{2}$ However, Antero called the stringent admissions processes 'the most important thing' that the government can do for teaching quality. Likewise, Masa said that pre-service teacher training was 'the most influential thing' in teacher-related policy, far more important 'incentives and disincentives and that kind of stuff'.

Singapore's teacher training programme is similarly selective, with one account stating that it admits roughly $12.5 \%$ of applicants (Butrymowicz, 2014), comparable to Finland's 11\% admission rate for class teacher education programmes in 2016 (Paronen and Lappi, 2018). However, Singaporean interview participants did not identify teacher training as an instrument for teacher accountability. The closest they came was Timothy mentioning that he had to apply twice before successfully getting a teacher training scholarship, and Andy saying that one of his lecturers had told their class of trainees that 'sometimes you do need to know when to blow your own trumpet' in order to get a good performance ranking.

Such ranking takes places through the EPMS. The EPMS is the education ministry's version of the national civil service appraisal system, which was itself based on the performance management system used by the Shell Petroleum Company in the 1980s (Ho and Koh, 2018; Liew, 2012; Neo and Chen, 2007; Quah, 2010). Central to the EMPS is its teaching career ladder, which has three 
tracks: teaching, leadership and senior specialist (Crehan, 2016b). The system sets performance standards in several key results areas under three outcome categories, which vary according to the teacher's position on the career ladder as well as their career track (Kan, 2014). To illustrate, Joseph said that:

Under the teaching track, there are three areas that they will look at. The first, nurturing the child, will encompass your subject and your form teacher responsibilities, as well as aspects of your CCA [i.e. cocurricular activity]. Then you have professional development—so, what are the training plans that you have? Another one is organisational contribution-so, what are the portfolios and school programmes that you actually contribute to?

This comprehensive, tiered system of standards contrasts with the approach described by Finnish interview participants, who emphasised the pedagogical freedom afforded by the curriculum. Besides EMPS structures, many interview participants also mentioned accountability instruments within their subject departments. Department-level instruments include standards for syllabus coverage and assessment frequency - and also for student achievement in the national standardised exams that loom large over the school system.

\section{Collecting and conveying information on teacher practice}

While test scores are pivotal to many teacher accountability systems, pupils in Finland do not take any national standardised tests until they reach the matriculation exam for university entry. Instead, in many schools, one source of information on teacher practice is an annual developmental discussion between each teacher and their principal (Kumpulainen and Lankinen, 2016). While every interview participant mentioned such discussions, some said that the discussions did not take place every year, or that they took place in groups of subject teachers rather than as targeted individual reviews. ${ }^{3}$ Most said that the discussions were informal in tone, involved two-way feedback and did not lead to any follow-up. In Maarit's account:

I think that the sitting down and talking are sometimes forgotten after that. I'll write down something fine, and then we talk, and then the year, every day continues, and probably now I don't even remember what I answered.

Apart from the developmental discussions, sources of information about teacher practice that were identified by interview participants include self-initiated collaborations between colleagues (e.g. to develop content for a particular unit, or to remedy a classroom problem), and discussions or lesson observations triggered by parental complaints. Such parent-triggered interventions appear to 
be rare, with participants mentioning only a few specific incidents over their careers. (That said, a few participants did mention that parents have become more demanding in recent years, especially in more socioeconomically privileged areas.)

Besides these relatively sparse instruments that collect and communicate information in order to directly influence teacher practice, there are some monitoring instruments that collect information on teacher practice in order to facilitate administrative decisions. The Finnish Education Evaluation Centre administers a system of sample-based tests to monitor national educational quality (Vainikainen et al., 2017). However, these sample-based tests do not play an accountability function in individual teachers' work. In Kristiina's words, 'I have never known anybody, or any school, or any teacher who has taken part of them. So they are not related to the everyday work of a teacher.' Similarly, Satu mentioned that her municipality collects feedback about some aspects of teacher practice and job satisfaction but added that:

It's not a very important thing for me when I'm working from Monday to Friday. I don't think it about it very much. [...] It's just a way to transfer the results to higher levels, but it doesn't come down to me again. [...] The municipality gives the money and the guidelines about what work you have to do. So they have to follow up about whether everything is okay, and if there are things to do better, in the future. It's important. But most of the teachers continue teaching the same way, and it doesn't affect them so much.

Each of Finland's municipalities - of which, in 2018, there were 311 (Statistics Finland, 2018) - has considerable decision-making power over local education (European Commission/EACEA/Eurydice, 2018b; Simola et al., 2009). As a result, some municipalities frequently collect information from teachers (Emilia: 'a massive amount of different questionnaires'), whereas others do not (Hannele: 'not at all').

On the other hand, under Singapore's centralised EPMS structures, all teachers regularly report on their work through formal channels that inform annual performance grades. These performance grades are awarded on the basis of several sources of information. At the beginning, middle and end of each school year, every teacher is required to document their targets and achievements on an EPMS form, and then to discuss their performance in a work review session with their reporting officer, i.e. a teacher with management-level responsibilities. Teachers are also observed in the classroom once a year by their respective reporting officers, who also examine a sample of students' work. These sources of information are then discussed at appraisal panels, where reporting officers triangulate each other's observations and compare teachers across each level of the career ladder, before allocating performance grades for the year. This can lead to 
the sense that teachers are constantly under observation by all reporting officers in the school. As Sonia said:

Every time someone walks by, you know you are being judged. Say you turn up five minutes late to the parade ground for assembly, you know that someone out there is eyeballing you and marking you down and saying, 'Okay, this is the person with the so-called punctuality problem.'

Besides heightening self-consciousness and stress among some teachers, the informational requirements of the EPMS generate substantial administrative work for reporting officers, who may have to appraise numerous colleagues (Eleanor: 'sometimes you have got a good ten staff to oversee, plus all the other admin work').

Although EPMS criteria do not officially include student test results, almost all participants mentioned accountability pressures from tests and exams, whether national exam results at the end of secondary school or school-level tests and exams throughout the year. Another frequently cited teacher accountability instrument was parental feedback. Participants gave varying accounts of the frequency and intensity of parental feedback, but it was clear that this feedback could sometimes be onerous. For instance, Mark said that 'parents expect the teachers to be on call 24/7 for student needs', and Maggie noted that some teachers use phone number masking services in order to forestall such $24 / 7$ contact.

Interestingly, Finnish and Singaporean participants had similarly mixed views on the extent to which professional collaborations with other teachers functioned as an accountability instrument. Among Finnish participants, some spoke of regular collaborations, especially with colleagues who teach the same subjects. However, others said that collaboration was infrequent or only happened in specific situations, such as adapting new curricular requirements to their school's needs. A few noted that levels of collaboration vary from school to school. Partly because of these differing levels of collaboration, participants also mentioned different degrees of accountability from colleagues, ranging from clear accountability relationships (e.g. Emilia: 'At least in this school, because we collaborate so much, it's more difficult to do things your own way, or to cut corners, or things like that') to tenuous ones (e.g. Satu: 'Nobody knows what I do in my classroom, [...] only myself and the students, but not my colleagues or the headmaster, nobody'). Likewise, some Singaporean participants did not mention peer collaboration at all, whereas some said that they collaborated regularly with colleagues, whether through formal departmental structures and professional learning communities or via informal information-sharing and self-initiated partnerships. One participant, Maggie, said that most Singaporean teachers 'hoard their materials and information quite a lot' - but also described an intensive, yearlong collaboration with a colleague as her proudest achievement in teaching. These similarly mixed pictures of professional collaboration among teachers contradict 
both the image of Finland as a haven of teacher professional collaboration (e.g. Strauss and Sahlberg, 2015), as well as the image of Singaporeans as relentlessly competitive, selfish people (e.g. Pierson, 2019).

\section{Allocating rewards and penalties}

Finland's teacher accountability instruments for allocating rewards and penalties are similar to its instruments for collecting information on teacher practice: they are usually unobtrusive, and they vary across municipalities. Rewards come in the form of small salary supplements for teachers who take on extra tasks that are otherwise uncompensated - rather than bonuses based on how well a teacher has performed their tasks. Some of these supplements are part of the union-negotiated salary structure, while others come from the municipality's discretionary budget. Supplements from the discretionary budget are allocated in different ways (e.g. Antero: based on the principal's decision; Liisa: based on an application to the municipality) and for different tasks, whether routine (e.g. Kristiina: 'if you take care of the annual choir performances at the school') or ad hoc (e.g. Emilia: 'a project which has touched the whole school'; Juhani: 'when there's been renovations in some schools, and you had to figure out new ways of teaching and change places a lot').

Although there may be some element of merit in awarding the supplements for ad hoc tasks or in how the routine tasks are allocated, most participants did not regard these supplements as merit-based. (In Masa's words: 'I see that as, "If you want to do this crap job, then we'll give you money for it." And some crazy person is going to be okay with that, whereas the rest are like, "Phew, thank goodness I don't have to do it."') Different municipalities distribute these salary supplements differently, and they can be so inconspicuous that two interview participants from the same school disagreed about whether or not these supplements existed. Where they do exist, participants regarded them as token sums (e.g. Liisa: 'around a hundred euros a month'; Emilia: 'a gift card somewhere for fifty euros or something'; Satu: 'the [salary] difference is very low, maybe you can buy one movie ticket'). As for penalties, besides the developmental actions that can be triggered by parental complaints, the only penalty that participants identified was the possibility of being fired for egregious misconduct, such as drunkenness or physical violence in school.

In contrast, every teacher in Singapore is eligible for an annual performance bonus - or subject to career progression penalties - based on their performance grade. According to Mark, top-performing teachers in Singapore can receive annual bonuses of up to 3.5 months' salary. Performance grades also affect the speed at which teachers are promoted through the career ladder. Additionally, good performance grades render teachers eligible for funded study leave (as noted by Maggie), whereas unsatisfactory grades lead to developmental coaching and extra monitoring (as noted by Jane and Joseph) and, eventually, firing (as noted by Maggie and Mark; see also Singapore Teachers' Union, 2014, 2015). 
A noteworthy feature of the EPMS is that performance grades do not derive solely from EPMS standards. Rather, as Geok Ling observed, 'It's criterionreferenced, and then it's also norm-referenced'. Within each school, performance grades are awarded on a forced curve that benchmarks teachers against colleagues of the same level of the career ladder. Official guidelines about the EPMS grading system are not publicly available, but one non-Ministry source says that approximately $30 \%$ of teachers receive $\mathrm{A}$ or $\mathrm{B}$ grades, $65 \%$ receive $\mathrm{C}$ grades and $5 \%$ receive D or E grades (McMillan, 2017). Most participants mentioned that the competitive grading system can generate stress and demotivation for some teachers, and that a small minority of teachers attempted to game the system (e.g. by shifting time away from classroom preparation towards more visible committee work). However, despite its inbuilt competitiveness, and despite participants' acknowledgement that the fairness of the grading system could vary vastly across schools and reporting officers, the EPMS did not appear to undermine collegiality among teachers. In Andy's words, 'We do recognise those who are deserving of credit because [...] something about them enables them to go above and beyond for the students, and we don't begrudge them if they are rewarded accordingly'.

\section{Compatibility among teacher accountability instruments}

In Finland, selection processes for admission into teacher training ensure that those who enter the profession are intrinsically motivated to do their jobs well, and carefully designed pre-service teacher training programmes ensure that teachers know what such effectiveness looks like. This lessens the need for standards, informational channels and reward systems for controlling the in-service processes and outputs of teachers' work. In this setting, such external controls are not only unnecessary, but also undesirable. As Deci and Ryan (2000) famously argue, extrinsic rewards and other forms of control can impinge on the sense of autonomy that is crucial to sustaining intrinsic motivation (see also Chapter 2 of this volume). Furthermore, several participants emphasised the need for teachers to have the freedom to use their skills and personalities to facilitate student learning as they see fit. Such autonomy would be incompatible with exhaustive standard-setting and information-gathering instruments.

Autonomy notwithstanding, the input standards are strong enough to lessen the risk that teachers will deviate from the overarching goals of the education system. The government's teacher accountability instruments may be concentrated at the point of entry into the profession, but these standards are sustained - and perhaps reinforced - over time. According to Päivi, an experienced teacher who had once been in school leadership before opting to return to the classroom:

When I was the headmaster, I had the idea that when young teachers come to the school, then we could learn so many new things from them. 
[...] But then I saw that, after a year or two, new teachers are just the same as old teachers. [...] But I wouldn't change it. Teachers are kind and they are caring and they are hoping for the children's best. And that's the way it is.

Thus, the rigorous input standards offset the risks generated by the sparseness of formal teacher accountability instruments for processes and outputs. The capacity of these standards for reducing deviation is also evident in the fact that Finland has consistently had the smallest between-school variance in PISA scores among OECD countries (with the exception of PISA 2003, when Iceland had a marginally lower variance, and PISA 2000, when Sweden and Iceland had lower variances; OECD, 2004, 2007, 2010, 2013, 2016; OECD and UNESCO Institute for Statistics, 2003).

In Singapore, the teacher accountability system hinges on extensive information and powerful extrinsic incentives. This means that it would be vulnerable to failure if either the information or the consequences proved inadequate. But this vulnerability is mitigated by the magnitude of the performance bonuses, which can influence teacher motivation considerably. (In Adeline's words: 'Singaporean teachers are very typical civil servants, and they like to have their various KPIs and know that if they meet them, they might get rewarded'.) Furthermore, EPMS job descriptions for management-level positions in the career ladder ensure that enough time is channelled towards collecting information on teacher practice. Peter, who had recently become a subject head, said the following about his promotion:

It has changed my outlook of who I am as a teacher. [...] Because I know that my performance is going to be evaluated in the lens of being a subject head, I guess that shifts my focus a little when it comes to how much I'm involved in things that aren't subject-related.

Thus, there is compatibility between the standard-setting, informational, and consequential elements of the EPMS. The standards designate resources for information collection (among other things), while information enables the allocation of consequences, which, in turn, shore up the influence of the standards.

Collectively, these EPMS instruments exert extensive government control over teachers' work. However, this impingement on teacher autonomy is somewhat mitigated because government expectations of teachers often converge with what teachers expect of themselves. In particular, several teachers mentioned that they appreciated the ministry's emphasis on both academic and socioemotional development. When asked whether ministry expectations overlapped with her own, Sonia said:

I think they do converge quite a bit. [...] Why I got into [teaching] was because I want to help mould the character of students, and it does give me a lot of satisfaction when I see my students perform well academically. 
Hence, good policy design softens teachers' experiences of extensive accountability instruments. While criticising some aspects of the EPMS, Timothy also said he was 'intrigued and amazed' at the comprehensiveness of its rubrics. Similarly, Maggie said that the ministry's pedagogical recommendations 'are not really giving you trouble; they actually make your life simpler'. Again, international assessment results offer further support: in 2015, Singapore topped the tables across all PISA and TIMSS subjects and levels (Martin et al., 2016a,b,; OECD, 2016).

\section{Summary}

As shown in Table 11.1, Singapore's teacher accountability system is far more extensive than Finland's in almost every respect. The sole exception is standard-setting at the point of entry to the teaching profession, which plays a bigger role in Finland than in Singapore. Besides these entry standards and the national curriculum, Finland's instruments for communicating information and allocating consequences for teacher practice are comparatively low-key and can vary considerably across schools and municipalities. In contrast, Singapore's EPMS structures for teacher accountability are highly centralised and influential. The pervasiveness of this performance management system is evident in the fact that every single Singaporean interview participant, when asked about teacher accountability instruments, mentioned EPMS key results areas, performance reporting forms, thrice-yearly work review sessions, performance grades and promotions.

\section{Different teacher accountability approaches, comparable efficacy?}

Given these stark differences between Finland's and Singapore's approaches to teacher accountability, how can we understand the high quality of teaching in both of these countries? One way to interpret this is that teacher accountability

TABLE 11.1 Summary of teacher accountability instruments in Finland and Singapore

\begin{tabular}{lll}
\hline & Finland & Singapore \\
\hline Setting standards & $\begin{array}{l}\text { National curriculum; strong } \\
\text { standards at the point of entry } \\
\text { to the teaching profession }\end{array}$ & $\begin{array}{l}\text { Extensive teacher performance } \\
\text { standards in the EPMS }\end{array}$ \\
$\begin{array}{l}\text { Communicating } \\
\text { information }\end{array}$ & $\begin{array}{l}\text { Annual developmental } \\
\text { discussions with the principal } \\
\text { in most schools }\end{array}$ & $\begin{array}{l}\text { Annual lesson observations; thrice- } \\
\text { yearly performance management } \\
\text { reports and discussions with } \\
\text { reporting officers }\end{array}$ \\
$\begin{array}{l}\text { Allocating } \\
\text { consequences }\end{array}$ & $\begin{array}{l}\text { Small salary supplements for } \\
\text { additional responsibilities; firing } \\
\text { for egregious behaviour }\end{array}$ & $\begin{array}{l}\text { Performance-based annual bonuses } \\
\text { and career progression }\end{array}$ \\
\hline
\end{tabular}


instruments are irrelevant to the quality of teachers' work and do not make any positive contribution to teacher practice. A second interpretation is that teacher accountability instruments can, in fact, contribute to teacher practice: disparate approaches to teacher accountability can be equally effective, as long as the instruments are well designed. A third possible interpretation agrees with the second in arguing that accountability instruments do affect teachers' work, but diverges from the second in further asserting accountability instruments have different effects depending on how well they fit the larger contexts in which they are embedded.

Based on the interviews I conducted as well as secondary sources, I believe that the third interpretation is the most plausible. Teacher accountability instruments can, indeed, influence teacher practice constructively - but only if the instruments are compatible with the macro and exo-contexts in which they are implemented. To give some suggestive evidence, Figure 11.1 summarises interview participants' responses when I asked them what would happen, hypothetically, if their country adopted the other country's approach to teacher accountability (i.e. if Finland introduced EPMS structures, or if Singapore removed the career ladder, formal teacher appraisal and performance bonuses). Note that I asked this question in an open-ended manner, so the statements in Figure 11.1 represent my summaries of participants' responses, rather than a set of statements presented to participants for their agreement or disagreement.

Regardless of their personal preferences, none of the participants believed that the other country's teacher accountability approach would definitely be preferred by most teachers and/or would improve education in their country. Several Singaporean participants said that they would personally prefer the non-competitive autonomy of Finland's approach - but even these participants doubted that it would work at the system level, because they anticipated that some teachers would dislike the relative lack of structure and the absence of performance-based reward. For example, Singaporean participant Maggie said that the Finnish approach would give her the flexibility to develop her teaching practice long term rather than focusing on short-term performance targets, but added that:

agree partially agree $\bigcirc$ disagree [ ] not mentioned during the interview

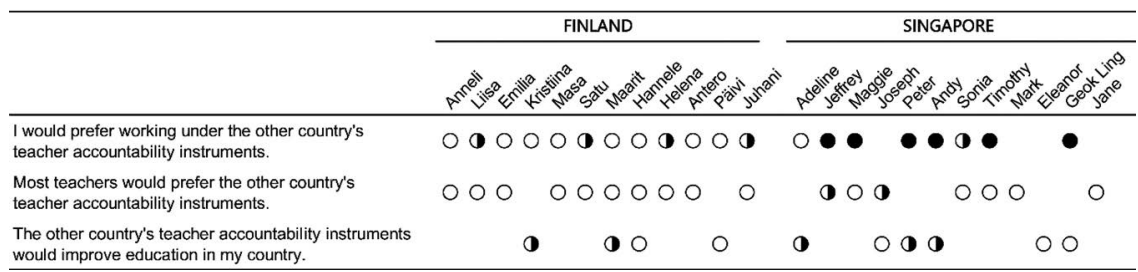

FIGURE 11.1 An summary of interview participants' answers when asked what would happen if, hypothetically, their country adopted the other country's teacher accountability instruments 
I think if you suddenly changed the system, most of the teachers will be very stressed because they have no idea what is being observed. Singaporeans find comfort, I think, in knowing exactly what is expected, and they like to do it to the letter.

Similarly, Finnish participant Juhani appreciated that Singapore's EPMS recognises good work and gives teachers a structured way of identifying their strengths and weaknesses but said that:

We are so independent here. And we like that independence in our classrooms so much, that even that bonus would not make this system a good thing. [...] And we are so equal, among teachers. [...] We do not want to give others the possibility of rushing higher. [...] We have done some studies about rewarding people with money, and it gives satisfaction for shorter period of time than when you are valued by the society you work in.

Given these responses, it seems unlikely that teacher accountability instruments have no influence on teachers' work, as in the first possible interpretation. And given how strongly participants reacted against the other country's accountability approach (e.g. Masa, describing Finnish teachers: 'They would quit. They would go on strike'; Sonia: 'The average Singaporean teacher will probably be up in arms'), it seems unlikely that any well-aligned set of accountability instruments could be equally effective in any given setting, as in the second possible interpretation. Internal coherence within a set of teacher accountability instruments may be necessary for efficacy, but it is not sufficient. ${ }^{4}$ Instead, as in the third interpretation, teacher accountability instruments need to be compatible with their respective macrosystems in order to be effective.

\section{Teacher motivation as the key to teacher accountability}

The key to making sense of Finland's and Singapore's disparate but comparably effective approaches to teacher accountability lies in (1) the relationship between accountability and motivation, and (2) the relationship between motivation and context. First, motivation - defined by Schunk et al. (2010, p. 4) as 'the process whereby goal-directed activity is instigated and sustained' - is closely connected to accountability. Whether implicitly or explicitly, accountability instruments targeting teacher practice assume that student outcomes can improve when teachers work harder, i.e. with raised motivation, and/or work differently, i.e. with motivation redirected towards different goals (see also Kozlowski and Lauen, 2019). Thus, teacher motivation is the linchpin of accountability instruments that successfully change teacher practice.

All three accountability mechanisms discussed in the previous section - setting standards, communicating information and allocating consequences - can influence teacher motivation, although they do so in different ways. For example, 
informational instruments influence teachers' motivation via their desire to be regarded favourably when information about their practice is compared to stakeholder expectations. When asked how accountability instruments affected his work, Timothy, a Singaporean interview participant, responded:

It's always at the back of one's mind. [...] Yeah, because you know that there are other people who are watching you, so to speak. [...] I would consider it a negative motivation, or not the most desired form of motivation. But at least it helps to spur you on when you are drained.

Informational instruments can vary greatly. There are many differences between, for example, a mandatory questionnaire on classroom activities and a self-initiated troubleshooting session with colleagues. Despite these differences, any information-based accountability instrument that successfully shapes teacher motivation does so by prompting teachers' desires to compare favourably to a set of expectations, whether codified or tacit, shared or unilateral, precise or vague, externally imposed or personally espoused.

These expectations may come from accountability instruments that set standards for teacher practice. Unlike the informational mechanism, which operates through teachers' awareness that they are being actively compared to a set of expectations, the standard-setting mechanism passively directs teacher motivation towards such expectations. Passivity notwithstanding, standards can be highly influential. For example, Satu said the following about Finland's national curriculum:

I have the basic rules there. So it's easier than thinking, 'Whoa, what I will do now?' The year is not empty. [...] And it's easier for the teacher to follow the curriculum than invent something by themselves.

As with informational instruments, standards can take on a variety of tones in a range of relational settings. Standards can safeguard community networks through shared norms, or channel competition towards remunerative targets.

Finally, and perhaps most obviously, some accountability instruments allocate consequences based on stakeholders' judgements of teacher practice - thus influencing teacher motivation via the desire to gain rewards and avoid penalties. When asked about the consequences of teacher performance grades, Geok Ling, a Singaporean teacher in middle management, said:

You know that, 'Okay, they're going to grade me like this, and this is how I can get more because of the bonus.' So people will drive their behaviour towards the criteria. [...] But you can argue that it's a necessary devil; it's a double-edged sword. While it may raise the standard and it motivates some, because they see it as an affirmation, it will also demoralise some. 
As Geok Ling observes, teachers' perspectives on accountability instruments can be heterogeneous, yielding heterogeneous effects on motivation.

To illustrate the degree to which accountability instruments may potentially change teacher motivation, consider interview participant Masa's description of Finland's new Kilpailukykysopimus (KIKY, i.e. competitiveness pact) policy. KIKY stipulates, among other things, that all full-time employees nationwide work an extra 24 hours annually without extra pay (SAK, 2016). This emphasis on regulating work hours is a clear departure from Finland's established approach to teacher accountability, in which careful selection processes and pre-service training construct a competent and motivated body of teachers who experience relatively few external controls over their day-to-day work. In Masa's view, the mismatch between KIKY stipulations and this established approach was damaging:

Teachers started complaining about being a teacher, which was new, for me. People were starting to think about changing jobs. Because all of a sudden, we've got this bureaucracy that's keeping track of this time. They're realising that we already do more than that anyway. And [...] now they're doing it for the time, which equates to money, rather than because something inside says, 'This is what needs to be done.' So the teachers' personal standards have dropped.

Although the new cross-sector KIKY policy may have eroded some intrinsic motivation, most Finnish interview participants emphasised the long-established internal standards that Masa also mentioned. They agreed that most Finnish teachers are highly motivated to teach well, despite the negligible rewards and penalties.

\section{How the macrosystem shapes teacher motivation and teacher accountability}

So, what matters in teacher accountability is not whether the accountability instruments are extensive (as in Singapore) or less extensive (as in Finland). Rather, what matters is that the instruments influence teacher motivation in ways that lead to desirable student outcomes. Like other professionals who serve multiple goals that are difficult to monitor and measure, teachers constantly and actively redistribute limited resources between numerous priorities (Lipsky, 2010; Murnane and Cohen, 1986). And they do not respond mechanistically to accountability instruments. Satu, who was quoted earlier speaking favourably about Finland's national curriculum, also said that:

Even if they make quite a big change to the curriculum, some teachers [...] may say, 'Huh, pfft. Waste of time. I'll do what I have done for the past thirty-five years.' 
Similarly, Maggie, a teacher from Singapore, observed that:

Let's say you have a top-down policy implementation. If you didn't trust [the teachers] with the discussion beforehand, then when you do implement it, they would just do whatever it takes to survive, and it might not turn out the way you want it. Like, they will modify it, just to placate you and show you some semblance of what you want to see.

Satu's and Maggie's remarks illustrate an argument advanced by Andrews et al. (2017, pp. 113-118) that effective public service delivery relies not only on the administrative apparatus of accountability but also on the alignment between each actor's duties and their sense of personal and social responsibility (see also McLaughlin, 1987).

Simply put, an accountability instrument will only influence a teacher's motivation positively if the teacher regards the instrument as sufficiently meaningful, legitimate or otherwise persuasive (Verger and Parcerisa, 2017). In their review of psychological research on how accountability affects social choices, Lerner and Tetlock (1999) found that accountability only leads to beneficial increases in cognitive effort when numerous contingent factors coincide. One such factor was whether the accountability instrument was seen as legitimate. Similarly, in an analysis of an accountability policy change in a US state, Kim et al. (2019) matched data from teacher self-report questionnaires with principal-reported evaluation ratings and found that teachers who viewed the new evaluation policies as legitimate were more likely to improve their instructional practice.

There is a close connection here between legitimacy and trust. As noted in Chapter 1 of this volume, trust depends on the perception that the recipient of the trust is competent, benevolent and has integrity. These three traits clearly (though not completely) overlap with the three traits that Kim et al. (2019) identify as key ingredients in regarding a policy as legitimate: whether its instruments are valid and reliable, which overlaps with competence; whether it is procedurally fair, which overlaps with integrity; and whether its intended outcomes are worthwhile, which is somewhat analogous to benevolence (see also Tyler, 2006). Hence, if a teacher believes that the design and intent of a teacher accountability instrument do reflect these traits, they are more likely to regard the instrument as legitimate.

However, as noted earlier, teachers face competing priorities in their daily work, and even a legitimate accountability instrument may not influence teacher motivation if it is superseded by other priorities, as in Satu's observations on how some Finnish teachers' respond to curricular change. Conversely, even if a teacher does not regard an instrument as trustworthy, it may still influence their motivation, as with Finland's KIKY stipulation that Masa described. Furthermore, as Singaporean participant Geok Ling observed, a legitimate accountability instrument can have heterogeneous effects, raising the motivation of some teachers while demotivating others. 
Heterogeneity notwithstanding, there will be some broad patterns in the accountability instruments that most teachers within a given setting regard as compelling. This is because teachers' perspectives and, in turn, the overall efficacy of teacher accountability instruments are shaped by context. As Pawson and Tilley (1997, p. 216) observe in their seminal work on realist policy evaluation, 'subjects will only act upon the resources and choices offered by a program if they are in conducive settings'. Similarly, Bronfenbrenner (1977, p. 515) observes that macrosystems 'set the pattern for the structures and activities occurring at the concrete level'. These macrosystems comprise societal 'blueprints', or 'the overarching institutional patterns of the culture or subculture' (Bronfenbrenner, 1977). Hence, the interview participants' vehement reactions against the other country's accountability approach: Finland's macrosystem is not a conducive setting for Singapore's EPMS, nor is Singapore's macrosystem a conducive setting for Finland's light-touch approach.

\section{Compatibility between teacher accountability instruments and macro-level trust}

How does this play out in Finland and Singapore? First, as shown earlier, each country's set of teacher accountability instruments is well designed, with compatibility between the instruments such that they collectively influence teacher motivation in desirable ways. Finland's teacher accountability instruments establish and orient high levels of teacher motivation at the point of entry into the teaching profession, while Singapore manages and motivates teachers' work throughout their careers through a system of interlocking standards, monitoring structures and performance-based consequences. But internal compatibility is not enough. Another factor in their successful approaches to teacher accountability is compatibility between their accountability instruments and the wider macrosystem. In the absence of such external compatibility, the accountability instruments would fail to influence teacher motivation as intended by policymakers, instead of having negative or null effects - as with Finland's KIKY regulations that may have compromised teachers' intrinsic motivation.

Teacher accountability is influenced by numerous interacting macrosystemic patterns. I focus here on one such pattern: the distribution of public trust in the education system. ${ }^{5}$ Whereas the absence of external compatibility between teacher accountability instruments and the macrosystem can yield negative or null effects, the presence of such external compatibility may result in a positive feedback loop. If the choice of teacher accountability instruments is aligned with the distribution of trust, this trust will legitimate the instruments, thus increasing their likelihood of raising or positively redirecting teacher motivation. These positive motivational changes may then improve classroom practice and student outcomes, which, in turn, will shore up trust in the education system. 
Finns and Singaporeans both place great trust in their education systems, but the distribution of this trust differs. In Finland, the trust is spread throughout every level of the education system, such that a great deal of trust is invested in teachers as highly trained and motivated professionals. In Singapore, however, the main locus of trust is the Ministry of Education and its capacity to coordinate and incentivise desirable activities throughout the education system. Accordingly, Finland's teacher accountability instruments aim to mobilise and empower teachers to work towards desirable student outcomes, whereas Singapore's teacher accountability instruments pursue the same aim by endowing the government with extensive capacities for shaping teachers' work. Following Cerna's (2014) terminology, the dominant form of trust in Singapore's education system is institutional trust in the Ministry of Education. In Finland, institutional trust in the government is certainly present, but it does not supersede what Cerna calls generalised trust in teachers.

\section{Finland: Generalised trust in teachers alongside standard-setting accountability instruments}

The generalised trust that Finnish teachers enjoy is a form of interpersonal trust. However, while particularised interpersonal trust in a particular teacher is based on first-hand interactions, generalised trust is instead based on a widely shared confidence in teachers' collective professional integrity. In Hannele's words:

I think Finnish people rely on the teachers. I hear people say all the time that, 'I know you have a good school. I know you have good teachers.' [...] They trust that we do our job.

This trust in teachers does not imply a lack of trust in other levels of the education system, but rather that teachers are trusted to have command over their own work. According to Helena:

It goes through the hierarchy. The Ministry of Education trusts the [National Agency for Education] to develop the curriculum based on certain things they've laid out. [...] And then they trust the municipalities to come up with the local curricula. And those municipalities trust the schools to come up with school-based curricula. And then the school administration trusts that the teachers will do something useful with the school curricula in the way that they deem best, using the books, materials, and methods they find best. And then I, as a teacher, trust that when I tell my students to do something, they will do it.

Thus, actors at each level of educational delivery are trusted to do what is expected in their respective spheres. 
In the sphere of the classroom, both the general public and the government trust that teachers will do their best. Consequently, this generalised trust in Finland's selected and highly trained teachers legitimates the relative lack of formal teacher accountability. In Antero's words:

When they selected me to study teaching, of course they checked that my personality and who I am fits the job. And after that, I have been on my own. Nobody has come here to say that, 'You must change. And you must do it like this, not like that.' I am in charge here.

Concurrently, the successful track record of this approach reinforces public trust in teachers. According to Liisa:

There haven't been any discussions about Finland adopting any teacher accountability instruments from other countries. I think there's a consensus that the thing runs well now, so there are no very big problems about teachers not doing what they're supposed to do. [...] We know what we need to do. So we don't need an extra system to tell us what to do in that way.

Hence, the highly motivated and trained people who succeed in entering the teaching profession enjoy a virtuous cycle of autonomy and public trust (see also Aho et al., 2006; Crehan, 2016a; Simola et al., 2017). As early as 1981, a Finnish government official spoke to an OECD delegation about 'the importance of traditional freedom for teachers in Finland' to choose their teaching methods, textbooks and curricular emphases (OECD, 1982). Despite this longstanding autonomy, Finnish teachers have not always been so highly esteemed. Simola (2014) observes that, prior to the 2000s, most Finns regarded the school system as good, though not exceptional, but some influential business leaders were criticising the system vociferously and advocating for more educational competition - until the 2001 release of PISA results silenced them. Thus, PISA league tables inadvertently served as an accountability instrument, conveying the information that Finland's teachers were collectively doing a good job, thus easing the national-level pressure to apply more accountability instruments to teachers.

Beyond education, an oft-cited indicator of generalised trust is the proportion of people answering affirmatively when asked whether 'most people can be trusted' or 'you need to be very careful in dealing with people'. In the European Values Study (EVS) 2008, Finland had the fourth highest proportion of respondents favouring generalised trust, only exceeded by Nordic neighbours Denmark, Norway and Sweden (EVS, 2016). While Finland and its Nordic counterparts did not participate in the more recent World Values Survey (WVS) 2010-2014, which included the same questionnaire item, only the Netherlands exceeded the proportion of Finnish EVS 2008 respondents favouring trust, and marginally so (WVS Association, 2015). 
This balanced distribution of trust works in tandem with another important macro-level value: a societal emphasis on egalitarianism. Both of these values are evident in Helena's account of how some foreign exchange students at their school reacted to school cafeteria food that seemed tasteless to them:

Their solution to it was very simple: 'Why don't you just tell the kitchen to make spicier food?' Which makes sense from the point of view of, 'The kitchen staff's job is to serve me food,' and, 'They're lower in the hierarchy.' But from our point of view, the kitchen is run by a company, which we buy the service of. And they're just people working in the kitchen. And they don't come and tell me how to teach maths, so I wouldn't feel like it was my job to tell them how to make food.

Finland's egalitarianism is evident in, among other things, its relative economic equality. During the 10 most recent years for which Gini data are available (2005-2015), Finland consistently had 1 of the 10 most equal income distributions in the world (World Bank, 2019). Finland also had the third highest score in Oxfam's 2018 Commitment to Reducing Inequality index (Lawson and Martin, 2018).

\section{Singapore: Institutional trust in the education ministry and extensive instruments for teacher accountability}

On the other hand, Singapore had the eighth lowest score in the same Commitment to Reducing Inequality index (Lawson and Martin, 2018). One interview participant, Jeffrey, suggested that Singapore's tightly packed urban geography facilitates ubiquitous stratification:

You're kind of fenced in. [...] So that very much forces you higher up on the value chain. You basically can't choose to slack off. [...] . I mean, you can say publish or perish-but you don't even have the option (laughter) in the education system. It's pass or distinction. That's it. (laughing) Because no matter how badly you do, they're going to put you somewhere, whether it's ITE [i.e. Institute of Technical Education], Normal (Tech), or Foundation. There's somewhere that they have specially designated for you.

Jeffrey's remarks imply not only socioeconomic stratification (with a 'value chain' and a ladder of educational prestige), but also political hierarchy (with constraints on individual agency, since you are 'fenced in' and 'they', i.e. the government, designate your place in society). The combination of hierarchical governance alongside educational and socioeconomic stratification pervades the public sphere in Singapore, having been fostered by the government under the banner of competitive, progress-oriented meritocracy throughout the second half of the 20th century (Lee, 2000; Tan, 2018; see also Teo, 2018; Tremewan, 
1994). Some interview participants expressed discomfort with this emphasis on achievement, meritocracy and competition - whether in the EPMS rewards system or in Singapore's macrosystem more broadly - but they also assumed that it was ingrained in both local culture and national governance and was unlikely to change.

One element of Singapore's sociopolitical stratification is a hierarchical distribution of trust and authority in the education system. In Singapore, public trust in the education system is not distributed throughout the system, as in Finland. Instead, it is concentrated on the government. In the WVS 2010-2014, Singapore had the fourth highest proportion of respondents - after China, Qatar and Azerbaijan - reporting that they had 'a great deal' or 'quite a lot' of confidence in their central government (WVS Association, 2015).

When I asked interview participants whether their lived experience supported the WVS finding that most Singaporeans were highly confident in public institutions, every participant agreed. (However, some added that younger generations have started to question the government.) The precedence of trust in government over trust in teachers was also evident in some participants' responses to the hypothetical question about Finland's teacher accountability approach. For example, Eleanor said that:

My immediate response is, it's not going to work. [...] It will be very teacher-dependent, and so it will be the luck of the draw if your child gets into this classroom where this teacher is a bit more progressive or has more initiative, then you benefit. Whereas in other classrooms where the teacher is just happy with what she or he is doing, then the child is not going to learn as much. So that inconsistency is something the government will not want to risk, because the feedback from the people will be quite strong. I think there is a great sense of entitlement here, where the people depend a lot on the government to get things done.

Andy's response shows a similar dynamic. Andy described himself as a 'happy ordinary teacher', a moniker adopted by some Singaporean teachers who prioritise classroom teaching over climbing the career ladder towards the ministry headquarters. After I told him about Finland's teacher accountability approach, Andy commented that those who would enter teaching under Finland's approach were likely to be happy ordinary teachers, ${ }^{6}$ and then said:

So if Singapore were to embark on such a system, it's possible that it might be better in terms of attracting the right kind of people. But yeah, where would we train all our bureaucrats? They need to experience life on the ground as well.

This consciousness of system-level needs over teachers' needs was a recurring theme in the Singapore interviews. 
Even though Singapore's distribution of trust differs from Finland's, its teacher accountability instruments are likewise matched to its respective distribution. This yields the same mutual reinforcement: the locus of trust legitimates the chosen instruments, and the efficacy of the instruments strengthens public trust. Specifically, high public trust in Singapore's government legitimates its considerable control over teachers' work. The strength of this trust is such that teachers generally accede to the extensive accountability instruments, despite any personal qualms they may have (see also Ee, 2018). For example, Timothy said:

To use a very civil service phrase, these [EPMS] expectations are all cascaded down from your ministers and the top policymakers. So what they would have in mind, I believe, is in line with what, hopefully, will help make the country a better one.

This affirmation of government authority is especially striking given, less than a minute earlier, Timothy had said that he had 'many reservations' about how the EPMS was carried out. Several participants displayed a similar sense of internal tension when they disagreed with government stances. However, others appeared very comfortable with the hierarchical authority. Furthermore, as Jane suggests, even those who feel internal discomfort may outwardly comply because of the government's success in educational and economic development:

They have confidence [in government institutions] because, all the while, the country has been doing well. But I think, slowly, some of the younger ones are questioning, and some of the older ones want to have some opposition [to the government]. But they don't want to rock the boat, because they're still very happy.

Since the government's extensive control over education and other aspects of public life has proved effective, most Singaporeans continue to trust government institutions. For now, at least, trust in the Singaporean government supports and is supported by - its extensive teacher accountability instruments, whereas public trust in teachers justifies the Finnish government's relatively sparse teacher accountability instruments, and the sustained efficacy of these instruments shores up trust in teachers. ${ }^{7}$

\section{Conclusion}

To summarise, Singapore's education ministry sets extensive standards for multiple areas of teacher practice, and the information collected on these areas informs market-oriented governance of the school system. However, departing from libertarian conventions, teachers and schools are not independent suppliers in a marketplace in which families seek their best options for educational consumption. 
(In fact, the scope of Singapore's educational market is constrained by the stipulation that Singaporean citizens who seek to enrol in private schools require individual authorisation from the ministry [Singapore Ministry of Education, 2018].) Rather, teachers are dependent on the ministry as the sole buyer of their services. Instead of competing for higher enrolments in their schools, teachers compete for larger bonuses and career development opportunities, which are overseen by the ministry. Yet this top-heavy approach to teacher accountability works because of public confidence in the government, alongside established macrosystemic emphases on hierarchy and competition.

In contrast, Finland's government sets strong standards for teacher practice at the point of entry to the teaching profession, but this exercise of hierarchy serves to enable and safeguard subsequent teacher autonomy. Autonomy notwithstanding, teachers in Finland do not conform to an idealised template of network governance. While teachers, school leaders, municipalities and national-level education authorities do work towards common goals as interdependent actors, the dominant logic is not collaborative decision-making, but rather individual responsibility within clearly demarcated domains. Hence, the degree of professional collaboration among teachers may vary from extensive to virtually non-existent. But, for the most part, teachers share a strong work ethic and a commitment to the egalitarian aims of the national curriculum. Thus, hierarchical standard-setting in Finland facilitates loose networks of autonomous teachers, whereas standard-setting in Singapore facilitates centralised quality improvement via professional competition for bonuses, promotions and prestige.

Differences notwithstanding, these successful approaches to teacher accountability share an underlying principle: compatibility between teacher accountability instruments and the macrosystem. Each education system gives the final say in teacher practice to the stakeholders that are most trusted with classroom matters, whether Finland's highly trained teachers or Singapore's highly mobilised education ministry. This compatibility helps to legitimise these instruments in teachers' eyes, which facilitates the influence of the accountability instruments over teacher motivation and teacher practice. In turn, the efficacy of the accountability instruments in facilitating desirable educational outcomes also legitimises public trust in Finland's teachers and Singapore's education ministry. As observed in Chapter 1, the trust often has a reciprocal nature, which can deepen over time.

In aiming for brevity, this discussion has veered into some generalisations. Finland's education system may be premised on egalitarianism, but this does not obliterate the influence of family socioeconomic background on educational pathways. In Helena's words: 'We have research information that students whose parents have academic [rather than vocational] schooling do better academically. [...] So it would be lying to say that doesn't exist'. Also, despite stratification in Singapore, the school system offers a high baseline of education even for the less privileged, given that the lowest socioeconomic quartile of Singaporean 15-year-olds outperformed the average OECD 15-year-old in PISA 2015 
science (OECD, 2016). Moreover, Finland and Singapore may differ greatly, but they are far from being binary opposites. For one thing, both countries share a society-wide affirmation of the value of education, as observed by interview participant Mark. Additionally, interview participants in both the countries expressed a strong sense of intrinsic motivation to teach well, despite the vast differences in the extrinsic incentive structures that circumscribe their work.

Still, the dominant macrosystemic patterns discussed here - about egalitarianism, stratification, autonomy and structure - need to be taken seriously in designing teacher accountability policy: for example, a teacher who grew up in an egalitarian education system may treat a norm-referenced performance bonus very differently from a colleague who was educated in a highly competitive and stratified system. Equally, a teacher who had been socialised to prize their professional autonomy might resent the introduction of detailed guidelines outlining their duties, whereas a teacher accustomed to relying on such guidelines might flounder if they were removed.

In this chapter, I have mapped one pathway through which the cultural macrosystem can have a pivotal influence on individual teacher's responses to exosystem-level policy. However, I am not suggesting that macrosystemic constraints necessarily limit any given education system to a single, culturally dictated model of teacher accountability. Neither I am suggesting that macro-level cultural patterns are the sole - or even the prime - influence on how teachers respond to accountability instruments. Social and professional behaviour is informed by numerous inputs. Even if certain sociocultural patterns are dominant and widely acknowledged in a given macrosystem, these patterns will not be universally shared (Maxwell, 2012). ${ }^{8}$ What I am arguing, in line with the other chapters in this volume, is that teacher accountability takes place in an ecosystem, in which different levels of the system can influence each other multidirectionally. While the cases of Finland and Singapore show how the macrosystem can offer orientations for effective teacher accountability policy, it is equally possible that teacher accountability instruments can shape teachers' macrosystemically situated conceptions of their work (especially when accountability structures are closely aligned with initial teacher training and other aspects of teachers' socialisation, as in Holloway, 2018; Holloway and Brass, 2018). When discussing and designing teacher accountability policy, the macrosystem and its distribution of trust matters - but so do other components of the system.

\section{Acknowledgements}

The research in this chapter was conducted as part of a $\mathrm{PhD}$ funded by the Gates Cambridge Trust (BMGF OPP1144). I am also grateful for fieldwork funding provided by the Faculty of Education and St Catharine's College at the University of Cambridge. 


\section{Notes}

1 Following Bovens' (2007, p. 450) definition of accountability as 'a relationship between an actor and a forum, in which the actor has an obligation to explain and to justify his or her conduct, the forum can pose questions and pass judgement, and the actor may face consequences', I formally define teacher accountability instruments as tools, practices, and structures that aim to orient teacher practice toward stakeholder expectations by (a) collecting information about teachers' individual or collective practice and communicating this information to stakeholders, (b) setting standards by which stakeholders judge teacher practice, and/or (c) allocating consequences based on stakeholders' judgements of teachers' practice.

2 I am grateful to Lucy Crehan for the observation that teacher accountability systems can concentrate their quality controls on different junctures, whether the inputs, processes or outputs of the teaching profession. Similarly, Oates $(2015$, p. 4) observes that the teaching profession in Finland emphasises 'front-end restrictions' rather than 'back-end' ones.

3 For comparison, in a 2017 survey, 65\% of Finnish teachers said they had had one developmental discussion during the prior 12 months, $27 \%$ said they had had two or more discussions, while $8 \%$ said they had not had any (OAJ, 2018, p. 31).

4 Interview participants' generally positive views about their country's respective approaches to teacher accountability do not mean that they were uncritical. In fact, some participants from both countries emphasised that they knew of colleagues who were not especially motivated to teach well, but nonetheless were allowed to remain in the profession. In Finland, this was partly because many teachers hold tenured positions (European Commission/EACEA/Eurydice, 2018a). In Singapore, this room for 'cruising', as some participants called it, could emerge from teachers' seniority, or from favourably misrepresenting one's work to the reporting officer (e.g. showcasing recommended pedagogical strategies only during scheduled lesson observations), or from what one participant called the 'very merciful' lower tiers of the grading system (although other participants disputed these mercies). Besides this room for slack performance, other criticisms raised by multiple participants included the lack of professional feedback on classroom practice in Finland, and the competitiveness, stress, and potential harm to teachers' self-esteem in Singapore. Notwithstanding such shortcomings, the overall picture painted by interview participants was of effective teacher accountability instruments within effective school systems.

5 When conducting these interviews, I was not specifically investigating the distribution of public trust in the education system. I did ask interview participants about some aspects of social capital (including generalised trust) and about how hierarchical/accountability egalitarian their countries were, due to pre-existing studies indicating that these sociocultural constructs may affect the influence of instruments (on social capital, see Iyengar, 2012; Webber, 2010; on hierarchy, see Broekman, 2016; Gelfand et al., 2004;Velayutham and Perera, 2004). However, I only posed these questions about social capital and hierarchy at the end of each interview, after asking more general questions about aspects of sociocultural context that influence education in their country, and that influence teachers' responses to accountability instruments. The centrality of the distribution of trust in the education system emerged from participants' responses to these questions, as well as other parts of the interviews.

6 Besides Andy, a few other participants noted that changing the teacher accountability approach would also change the type of person who became a teacher, implying that a self-selection effect might influence the efficacy of teacher accountability. Even so, such self-selection would not be sufficient for effective teacher accountability if the accountability instruments were at odds with the macrosystem. As noted above, several Singaporean participants said that, on a personal level, they would strongly prefer Finland's teacher accountability approach over Singapore's.Yet they persist in Singapore's teaching profession despite their aversion to its accountability approach, thus showing 
that the self-selection mechanism is not all-encompassing - unlike the macrosystem, which influences every teachers' response to accountability instruments, albeit to different degrees.

7 Besides macrosystemic trust, there are other identifiable aspects of Finland's and Singapore's sociocultural contexts that have a mutually reinforcing interaction with each country's approach to teacher accountability. As I argue elsewhere, Finnish and Singaporean interview participants had distinctly different mental models of the factors that raised and lowered their motivation, and their respective mental models were compatible with each education system's respective accountability approach (Hwa, 2019).

8 Moreover, I suspect that Finland and Singapore may both benefit from relatively strong societal consensus about certain values and priorities - perhaps resulting from small populations and relative institutional stability, among other factors. If my hunch is true, such sociocultural alignment may offer clearer orientations for context-sensitive policymaking than would be present in many other education systems.

\section{References}

Aho, E., Pitkanen, K., \& Sahlberg, P. (2006). Policy Development and Reform Principles of Basic and Secondary Education in Finland Since 1968 (No. 36871). Retrieved from World Bank website: http://documents.worldbank.org/curated/en/124381468038093074/Policydevelopment-and-reform-principles-of-basic-and-secondary-education-in-Finlandsince-1968.

Andrews, M., Pritchett, L., \& Woolcock, M. (2017). Building State Capability: Evidence, Analysis, Action. Oxford, NY: Oxford University Press.

Bovens, M. (2007). Analysing and assessing accountability: A conceptual framework. European Law Journal, 13(4), 447-468.

Broekman,A. (2016).The effects of accountability:A case study from Indonesia (pp. 72-96). In: J.Evers \& R. Kneyber (Eds.), Flip the System: Changing Education from the Ground Up (Online edition). Oxford; New York: Routledge. https://doi.org/10.4324/9781315678573.

Bronfenbrenner, U. (1977). Toward an experimental ecology of human development. American Psychologist, 32(7), 513-531.

Butrymowicz, S. (2014). Lessons from abroad: Singapore's secrets to training world-class teachers. The Hechinger Report, February 10. Retrieved 5 April 2019, from The Hechinger Report website:https://hechingerreport.org/lessons-from-abroad-singapores-secrets-totraining-world-class-teachers/.

Cerna, L. (2014). Trust: What it is and Why it Matters for Governance and Education [OECD Education Working Papers]. Retrieved from OECD website: http://www.oecd-ilibrary. org/content/workingpaper/5jxswcg0t6wl-en.

Crehan, L. (2016a). Cleverlands. London: Randon House.

Crehan, L. (2016b). Exploring the Impact of Career Models on Teacher Motivation. Paris: International Institute for Educational Planning, International Institute for Educational Planning, UNESCO.

Crouch, D. (2015). Highly trained, respected and free: Why Finland's teachers are different. The Guardian, June 17. Retrieved from https://www.theguardian.com/education/2015/ jun/17/highly-trained-respected-and-free-why-finlands-teachers-are-different.

Deci, E. L., \& Ryan, R. M. (2000). The 'what' and 'why' of goal pursuits: Human needs and the self-determination of behavior. Psychological Inquiry, 11(4), 227-268.

Ee, D. (2018). A Monopoly over Morality: How Moral Issues Are Publicly Resolved in Singapore (Unpublished B.A.Thesis). New Haven, CT:Yale University. 
European Commission/EACEA/Eurydice (2018a). Finland: Conditions of Service for Teachers Working in Early Childhood and School Education. EACEA, December 27. Retrieved 23 April 2019, from Eurydice website: https://eacea.ec.europa.eu/national-policies/ eurydice/content/conditions-service-teachers-working-early-childhood-and-schooleducation-24_en.

European Commission/EACEA/Eurydice (Ed.), (2018b). Teaching Careers in Europe: Access, Progression and Support. Luxembourg: Publications Office of the European Union.

EVS (2016). European Values Study 2008 - Integrated Dataset (ZA4800) Variable Report No. 2016|2. gesis, April 15. Retrieved from https://dbk.gesis.org/dbksearch/sdesc2. asp?no=4800\&db=e\&doi=10.4232/1.12458.

Finnish National Board of Education (2013). Teachers in Finland- Trusted Professionals. Retrieved from http://www.oph.fi/download/148962_Teachers_in_Finland.pdf.

Gelfand, M. J., Lim, B. -C., \& Raver, J. L. (2004). Culture and accountability in organizations: Variations in forms of social control across cultures. Human Resource Management Review, 14(1), 135-160.

Hepburn, H. (2017). Scotland eyes Singapore in 'radical' overhaul of teaching career paths. Tes, June 23. Retrieved from https://www.tes.com/news/scotland-eyes-singapore-radicaloverhaul-teaching-career-paths.

Ho, J. -M., \& Koh, T. -S. (2018). Historical development of educational leadership in Singapore (pp. 29-83). In: T. -S. Koh \& D. Hung (Eds.), Leadership for Change: The Singapore Schools' Experience. Hackensack, NJ: World Scientific.

Holloway, J. (2018). Teacher evaluation as an onto-epistemic framework. British Journal of Sociology of Education, 40(2), 174-189.

Holloway, J., \& Brass, J. (2018). Making accountable teachers: The terrors and pleasures of performativity. Journal of Education Policy, 33(3), 361-382.

Hwa, Y. (2019). Teacher accountability policy and sociocultural context: A cross-country study focusing on Finland and Singapore (Doctoral thesis). https://doi.org/10.17863/ CAM.55349.

Iyengar, R. (2012). Social capital as the catalyst for school participation. Compare, 42(6), 839-862.

Kan, Y. (2014). Your appraisal and career planning process streamlined. Contact: The Teachers' Digest, (14), 14-15.

Kim, J., Sun, M., \& Youngs, P. (2019). Developing the “will”: The relationship between teachers' perceived policy legitimacy and instructional improvement. Teachers College Record, 121(3), 1-44.

Kozlowski, K. P., \& Lauen, D. L. (2019). Understanding teacher pay for performance: Flawed assumptions and disappointing results. Teachers College Record, 121(2), 6.

Kumpulainen, K., \& Lankinen, T. (2016). Striving for educational equity and excellence: Evaluation and assessment in Finnish basic education (pp. 71-82). In: H. Niemi, A. Toom, \& A. Kallioniemi (Eds.), Miracle of Education: The Principles and Practices of Teaching and Learning in Finnish Schools. Rotterdam: Sense Publishers. (2nd revised edition).

Lawson, M., \& Martin, M. (2018). The Commitment to Reducing Inequality Index 2018: A Global Ranking of Governments Based on What They are Doing to Tackle the Gap Between Rich and Poor. https://doi.org/10.21201/2018.3415.

Lee, K. Y. (2000). From Third World to First: The Singapore Story, 1965-2000. New York: HarperCollins Publishers.

Lerner, J. S., \& Tetlock, P. E. (1999). Accounting for the effects of accountability. Psychological Bulletin, 125(2), 255-275.

Liew, W. M. (2012). Perform or else: The performative enhancement of teacher professionalism. Asia Pacific Journal of Education, 32(3), 285-303. 
Lipsky, M. (2010). Street-Level Bureaucracy: Dilemmas of the Individual in Public Service (30th Anniversary Edition). New York: Russell Sage Foundation.

Malinen, O. -P., Väisänen, P., \& Savolainen, H. (2012). Teacher education in Finland: A review of a national effort for preparing teachers for the future. Curriculum Journal, 23(4), 567-584.

Martin, M. O., Mullis, I.V. S., Foy, P., \& Hooper, M. (2016a). TIMSS 2015 International Results in Mathematics. Retrieved from http://timss2015.org/wp-content/uploads/filebase/ full\%20pdfs/T15-International-Results-in-Mathematics.pdf.

Martin, M. O., Mullis, I.V. S., Foy, P., \& Hooper, M. (2016b). TIMSS 2015 International Results in Science. Retrieved from http://timss2015.org/wp-content/uploads/filebase/full\%20 pdfs/T15-International-Results-in-Science.pdf.

Maxwell, J. A. (2012). A Realist Approach for Qualitative Research. Los Angeles, CA: SAGE Publications.

McLaughlin, M.W. (1987). Learning from experience: Lessons from policy implementation. Educational Evaluation and Policy Analysis, 9(2), 171-178.

McMillan, C. (2017). Churchill Fellowship Report:To Investigate How Public Education Systems of Government in Singapore and Finland Develop and Prepare Leaders. Retrieved from Winston Churchill Memorial Trust website: https://www.churchilltrust.com.au/media/fellows/ McMillan_C_2015_educational_leaders_and_increased_autonomy.pdf.

Muhonen, S. (2017). In Finland, it's easier to become a doctor or lawyer than a teacherHere's why. News blog, October 16. Retrieved 22 February 2019, from The Hechinger Report website: https://hechingerreport.org/teacher-voice-in-finland-its-easier-tobecome-a-doctor-or-lawyer-than-a-teacher-heres-why/.

Murnane, R. J., \& Cohen, D. K. (1986). Merit pay and the evaluation problem: Why most merit pay plans fail and a few survive. Harvard Educational Review, 56(1), 1-18.

Nelson, L. (2016,). What the US could learn from Singapore about making teachers better. Vox, January 15. Retrieved 28 February 2019, from Vox website: https://www.vox. com/2016/1/15/10773592/teachers-singapore-shanghai-professional-development.

Neo, B. S., \& Chen, G. (2007). Dynamic Governance: Embedding Culture, Capabilities and Change in Singapore. Hackensack, NJ: World Scientific.

OAJ. (2018) Opetusalan työolobarometri 2017 [Barometer of Teachers' Working Conditions] (OAJ:n julkaisusarja 5:2018). Retrieved from OAJ (Trade Union of Education in Finland) website: https://www.oaj.fi/ajankohtaista/julkaisut/2018/opetusalan-tyoolobarometri/.

Oates,T. (2015). Finnish Fairy Stories. Retrieved from Cambridge Assessment website: https:// www.cambridgeassessment.org.uk/Images/207376-finnish-fairy-stories-tim-oates.pdf.

OECD (1982). Reviews of National Policies for Education: Finland. Paris: OECD Publishing.

OECD (2004). Learning for Tomorrow's World: First Results from PISA 2003. In: PISA. https:// doi.org/10.1787/9789264006416-en.

OECD (2007). PISA 2006: Science Competencies for Tomorrow's World: Analysis (Volume 1). In: PISA. https://doi.org/10.1787/9789264040014-en.

OECD (2010). PISA 2009 Results: Overcoming Social Background: Equity in Learning Opportunities and Outcomes (Volume II). In: PISA. https://doi.org/10.1787/9789264091504-en.

OECD (2013). PISA 2012 Results: Excellence through Equity: Giving Every Student the Chance to Succeed (Volume II). In: PISA. https://doi.org/10.1787/9789264201132-en.

OECD (2016). PISA 2015 Results: Excellence and Equity in Education (Volume I). Retrieved from http://dx.doi.org/10.1787/9789264266490-en.

OECD, \& UNESCO Institute for Statistics (2003). Literacy Skills for the World of Tomorrow: Further Results from PISA 2000. In: PISA. https://doi.org/10.1787/9789264102873-en.

Paronen, P., \& Lappi, O. (2018). Finnish Teachers and Principals in Figures (No. 2018:4). Retrieved from Finnish National Agency for Education website: https://www.oph.fi/ download/189802_finnish_teachers_and_principals_in_figures.pdf. 
Pawson, R., \& Tilley, N. (1997). Realistic Evaluation. London: SAGE Publications.

Pierson, D. (2019). Singapore's 'kiasu' culture makes FOMO look like child's play. Los Angeles Times. January 18. Retrieved from https://www.latimes.com/world/asia/ la-fg-singapore-kiasu-fomo-20190118-story.html.

Quah, J. S. T. (2010). Public Administration Singapore-Style. Bingley, UK: Emerald Publishing. https://doi.org/10.1108/S0732-1317(2010)19.

Sahlberg, P. (2015). Finnish Lessons 2.0: What Can the World Learn from Educational Change in Finland? (2nd edition). New York: Teachers College Press.

SAK (2016). The competitiveness pact in brief. SAK, March 7. Retrieved 21 February 2019, from SAK:The Central Organisation of Finnish Trade Unions website: https://www.sak. fi/en/whats-new/news/competitiveness-pact-brief.

Schunk, D. H., Pintrich, P. R., \& Meece, J. L. (2010). Motivation in education: Theory, research, and applications. In: Pearson Educational International (3rd edition, International edition). London: Pearson, Merrill, Prentice-Hall.

Sclafani, S., \& Lim, E. (2008). Rethinking Human Capital in Education: Singapore as a Model for Teacher Development. Retrieved from Aspen Institute website: http://eric. ed.gov/?id=ED512422.

Simola, H. (2014). The Finnish Education Mystery: Historical and Sociological Essays on Schooling in Finland (1st edition). London; New York: Routledge.

Simola, H., Kauko, J., Varjo, J., Kalalahti, M., \& Sahlstrom, F. (2017). Dynamics in Education Politics: Understanding and Explaining the Finnish Case. Abingdon, Oxfordshire; New York: Routledge.

Simola, H., Rinne, R., Varjo, J., Pitkänen, H., \& Kauko, J. (2009). Quality assurance and evaluation (QAE) in Finnish compulsory schooling: A national model or just unintended effects of radical decentralisation? Journal of Education Policy, 24(2), 163-178.

Singapore Ministry of Education (2018). Admissions: Returning Singaporeans: Other information. MOE, May 23. Retrieved 22 April 2019, from Ministry of Education website: https:// www.moe.gov.sg/admissions/returning-singaporeans/other-information.

Singapore Teachers' Union (2014). Performance \& expectations - The 'D' grade. The Mentor, Term, 4-5.

Singapore Teachers' Union (2015). Revisions to the performance review process. The Mentor, Term, 4 .

Statistics Finland (2018). Finland in Figures 2018. Retrieved from http://www.stat.fi/tup/ julkaisut/tiedostot/julkaisuluettelo/yyti_fif_201800_2018_19693_net.pdf.

Strauss, V., \& Sahlberg, P. (2015). Teach for Finland? Why it won't happen. Washington Post, February 12. Retrieved from https://www.washingtonpost.com/news/answer-sheet/ wp/2015/02/12/teach-for-finland-why-it-wont-happen/.

Tan, K. P. (2018). Singapore: Identity, Brand, Power (1st edition). Cambridge, UK: Cambridge University Press. https://doi.org/10.1017/9781108561273.

Teo,Y.Y. (2018). This Is What Inequality Looks Like. Singapore: Ethos Books.

Tirri, K. (2014). The last 40 years in Finnish teacher education. Journal of Education for Teaching, 40(5), 600-609.

Tremewan, C. (1994). The Political Economy of Social Control in Singapore. Retrieved from https://www.palgrave.com/gb/book/9781349235124.

Tyler,T. R. (2006). Psychological perspectives on legitimacy and legitimation. Annual Review of Psychology, 57(1), 375-400.

United Nations (2017). World Population Prospects: The 2017 Revision, Key Findings and Advance Tables (No. ESA/P/WP/248). Retrieved from United Nations, Department of Economic and Social Affairs, Population Division website: https://population.un.org/ wpp/Publications/Files/WPP2017_KeyFindings.pdf. 
Vainikainen, M. -P., Thuneberg, H., Marjanen, J., Hautamäki, J., Kupiainen, S., \& Hotulainen, R. (2017). How do Finns know? Educational monitoring without inspection and standard setting (pp. 243-259). In: S. Blömeke \& J. -E. Gustafsson (Eds.), Standard Setting in Education:The Nordic Countries in an International Perspective. Cham, Switzerland: Springer. https://doi.org/10.1007/978-3-319-50856-6_14.

Velayutham, S., \& Perera, M. H. B. (2004). The influence of emotions and culture on accountability and governance. Corporate Governance, 4(1), 52-64.

Verger,A., \& Parcerisa, L. (2017).A difficult relationship. Accountability policies and teachers: International evidence and key premises for future research (pp. 241-254). In International Handbook of Teacher Quality and Policy. New York: Routledge. https://doi.org/10.5281/ zenodo. 1256602 .

Webber, D. J. (2010). School district democracy: School board voting and school performance. Politics and Policy, 38(1), 81-95.

World Bank (2019). World Development Indicators: GINI Index. Retrieved 26 February 2019, from DataBank website: https://databank.worldbank.org/data/reports.aspx?source $=2 \&$ series $=$ SI.POV.GINI\& country $=$.

WVS Association (2015). World Values Survey (2010-2014): Crossings by Country. Retrieved from World Values Survey Association website: http://www.worldvaluessurvey.org/ WVSDocumentationWV6.jsp. 